\title{
PENALARAN ASOSIATIF DAN DISOSIATIF DALAM DEBAT POLITIK DI TELEVISI
}

\author{
Mohamad Jazeri \\ Sekolah Tinggi Agama Islam Negeri Tulungagung \\ email: abahfuad@yahoo.co.id
}

\begin{abstract}
Abstrak
Penelitian ini bertujuan menjelaskan penalaran asosiatif dan disosiatif dalam perdebatan politik. Sumber data penelitian ini adalah peristiwa komunikasi dalam debat politik yang muncul pada era reformasi, menjelang pemilu 2009. Analisis data dilakukan dengan alur analisis data kualitatif yang diadopsi dari Miles dan Huberman. Hasil analisis menunjukkan bahwa penalaran asosiatif meliputi kuasi-logis, analogi, generalisasi, kausalitas, dan ko-eksistensial. Penalaran disosiatif meliputi kebijakan dan disosiasi ideologis. Perbedaan perspektif menyebabkan perbedaan cara memandang terhadap isu-isu politik dan kompleksitas perdebatan. Penalaran dalam perdebatan politik memiliki dua kepentingan, yakni rasionalitas untuk menghasilkan argumen yang sehat dan kepentingan kelembagaan untuk mencapai agenda politik.
\end{abstract}

Kata kunci: penalaran, asosiatif, disosiatif, dan debat politik.

\section{ASSOCIATIVE AND DISSOCIATIVE REASONING IN POLITICAL DEBATES ON TELEVISION}

\begin{abstract}
This study aims to explain the associative and dissociative reasoning in political debates. The data sources were communication events in the political debates emerging in the reform era, before the 2009 general election. The data were analyzed using a qualitative data analysis adopted from Miles and Huberman. The findings show that associative reasoning includes quasi-logic, analogy, generalization, causality, and co-existence. Dissociative reasoning includes policy and ideological dissociation. The difference in perspectives results in the difference in the ways of looking at political issues and debate complexity. Reasoning in political debates has two objectives, namely rationality to produce sound arguments and institutional interests to achieve a political agenda.
\end{abstract}

Keywords: reasoning, associative, dissociative, political debate

\section{PENDAHULUAN}

Sebagai sesuatu yang baru di Indonesia, debat politik di TV, baik debat Caleg maupun debat Capres-Cawapres, langsung mendapat sambutan baik dari pemirsa TV. Hal itu terlihat dari tingginya animo pemirsa TV di Indonesia untuk melihat tayangan debat politik yang menampilkan calon-calon wakil mereka. Sebagaimana pemirsa di studio, pemirsa di rumah pun terbelah menjadi dua, yakni sebagian mendukung tim afirmatif dan sebagian yang lain mendukung tim negatif.

Karena, debat politik bertujuan meyakinkan khalayak pemilih, kemampuan bernalar memegang peranan penting. Para politisi harus memiliki kemampuan penalaran yang baik agar mampu mendukung klaim-klaim politiknya dengan alasan-alasan yang logis sehingga mampu meyakinkan rakyat. Dalam debat politik, keterampilan penalaran dapat dilihat dari pendirian yang dipilih dan alasan 
yang mendukung pendirian tersebut. Meskipun demikian, dalam debat politik pendirian dan alasan dapat dikonstruk sedemikian rupa agar argumen terlihat logis dan menyakinkan rakyat walaupun kadang tersembunyi kebohongan. Karena itu, Hess-Luttich (2007) menyebut debat politik sebagai permainan ganda antara menghadirkan argumen rasional dan menghindarinya pada saat yang sama.

Dalam debat, para peserta melakukan aktivitas akal budi. Sullivan (1963) menjelaskan bahwa akal budi melakukan kegiatan dalam tiga tindakan, yakni pemahaman sederhana (simple apprehention), penilaian (judgment), dan penalaran (reasoning). Berkaitan dengan operasi akal budi ketiga, yakni penalaran, Copi (1978:5) menjelaskan bahwa penalaran merupakan kegiatan, proses, atau aktivitas berpikir untuk menarik suatu simpulan atau membuat suatu pernyataan baru berdasar pada beberapa pernyataan yang diketahui benar ataupun yang dianggap benar yang disebut premis. Warnich dan Inch (1994) menyatakan bahwa penalaran merupakan tindak menghubungkan antara bukti (sesuatu yang sudah diketahui dan diterima kebenarannya) dengan pendirian (sesuatu yang belum diketahui atau kontroversial). Dari dua definisi di tersebut jelas bahwa ada kesamaan antara penalaran dan argumen. Bedanya, penalaran itu aktivitas pikiran yang abstrak sedangkan argumen ialah lambangnya yang berbentuk bahasa atau bentuk-bentuk lambang lainnya.

Debat politik merupakan kegiatan adu argumen antara dua politisi atau lebih yang masing-masing berusaha mempengaruhi orang lain untuk menerima program yang disampaikan. Dalam debat politik, pembicara berusaha meyakinkan lawan bicara dan khalayak dengan menyertakan alasan, bukti, dan contoh yang sulit dibantah oleh lawannya. Begitu juga yang dilakukan oleh lawan debatnya. Mereka menunjukkan argumen yang kuat sembari mencari celah kelemahan dan kekurangan lawan. Dalam debat politik juga sering terjadi saling menjatuhkan antara peserta satu dengan lawannya sehingga debat politik juga disebut "the battle talk" (Hes-Lettich, 2007), yang sering menggunakan kekerasan verbal (Luginbuhl, 2007). Karena peserta debat berada dalam posisi setara, maka wacana-kontra wacana dilihat sebagai perselisihan simbolik (Rahardjo, 2007: v).

Debat politik biasanya terjadi menjelang pemilu. Elit politik berusaha mempengaruhi dan meyakinkan calon pemilih dengan program-program yang bagus disertai argumentasi yang kuat. Ketika pemilih semakin cerdas dan sadar berpolitik, maka debat politik memiliki pengaruh yang signifikan terhadap kecenderungan pemilih memberikan suaranya. Berbagai hasil survei membuktikan bahwa elit politik atau partai yang menawarkan program bagus semakin populer dan mendapat dukungan pemilih.

Secara kategoris, penalaran dalam debat politik di TV dapat dibedakan menjadi penalaran asosiatif dan penalaran disosiatif. Hal ini didasarkan pembagian skema penalaran menurut Parelman dan Olberchts-Tyteca (dalam Dawud 1998). Mereka menyatakan bahwa penalaran dapat dibedakan dalam skema asosiatif dan skema disasosiatif. Penalaran asosiatif memasukkan beberapa unsur penalaran dan mengevaluasi serta mengorganisasikan unsur satu dengan unsur lainnya. Sementara itu, penalaran disosiatif merupakan tindakan berpikir untuk membedakan satu gagasan dari gagasan lainnya dan berusaha menilai kedua gagasan tersebut. Penalaran ini mensyaratkan adanya hirarkhi nilai yang diyakini oleh pelakunya, yaitu keyakinan bahwa gagasan yang satu lebih baik nilainya dibanding gagasan lainnya.

Dari uraian di atas, muncul pertanyaan (1) bagaimanakah penalaran asosiatif dalam debat politik di TV? dan (2) bagaimanakah penalaran disosiatif dalam 
debat politik di TV? Itulah pertanyaan besar yang akan dideskripsikan dan dijelaskan dalam penelitian ini.

\section{METODE PENELITIAN}

Penelitian ini merupakan penelitian kualitatif sehingga analisis data dilakukan dengan alur analisis data kualitatif yang diadopsi dari Miles dan Huberman (1992). Karena debat politik penuh dengan muatan kepentingan, untuk mengetahui makna sebenarnya dibalik teks digunakan analisis pesan politik model Vedung (1982). Sumber data penelitian ini adalah peristiwa komunikasi dalam debat politik yang muncul pada era reformasi, khususnya menjelang pemilu 2009. Debat politik yang dimaksud adalah debat Caleg dan debat Capres-Cawapres. Debat Caleg ditayangkan dalam program DEBAT PARTAI yang ditayangkan oleh stasiun televisi swasta berskala nasional, yakni TV One. Sementara itu debat Capres-Cawapres ditayangkan oleh beberapa TV nasional seperti RCTI, ANTV, SCTV, TV One, dan lain-lain.

\section{HASIL DAN PEMBAHASAN}

Dalam wacana interaksional face-toface sebagaimana dalam debat politik, penalaran dikonstruk sedemikian rupa agar tujuan debat politik tercapai. Tujuan yang dimaksud adalah secara rasional argumen dapat dipertanggungjawabkan dan secara politis tujuan-tujuan politik praktis juga tercapai. Untuk menjelaskan hal tersebut, penalaran dibedakan dalam skema penalaran asosiatif dan skema penalaran disosiatif. Skema asosiatif meliputi quasi logis, analogi, generalisasi, kausalitas, dan koeksistensial.Sedangkan skema disosiasi meliputi disosiasi nilai dan kebijakan.

\section{Penalaran Asosiatif}

Penalaran asosiatif dalam debat, politik di TV memiliki beberapa varian, yakni quasi logis, analogi, generalisasi, kausalitas, dan koeksistensial. Berikut ini disajikan hasil penelitian tersebut beserta penjelasannya.

Quasi logis merupakan bentuk penalaran yang menempatkan dua atau tiga unsur yang saling berhubungan seperti hubungan antarunsur dalam logika formal. Bentuk penalaran ini memiliki tiga varian, yakni transitivitas, ketidaksesuaian, dan pertukaran. Berikut ini adalah contoh data penalaran quasi logis.

\section{Quasi logis transitivitas}

Quasi logis transitivitas memiliki tiga terma yang saling berkaitan, tetapi hubungan antara terma-terma itu bersifat kemungkinan (bandingkan dengan silogisme kategorik dan entimem). Data berikut patut diperhatikan.

\section{[1] PKS:}

Semua partai mitra koalisi pemerintah harus mendukung kebijakan kenaikan BBM. Sebagai mitra koalisi PKS ikut mendukung. (2.1.1.A1.01)

menjadi:

Proposisi di atas dapat diuraikan

Premis Mayor :

Semua partai mitra koalisi harus mendukung pemerintah.

Premis Minor :

PKS adalah mitra koalisi pemerintah.

Konklusi :

PKS harus mendukung kebijakan pemerintah.

Penalaran di atas dilakukan oleh PKS dalam menanggapi PAN yang keberatan dengan kebijakan pemerintah menaikkan harga BBM. Memang sejak diumumkan, kenaikan harga BBM banyak mendapat penolakan di mana-mana. Besarnya penolakan itu dapat dilihat dari banyaknya demo mahasiswa, LSM, dan ibu-ibu rumah tangga yang marak digelar diberbagai daerah. Karena itu, PKS sebagai mitra koalisi pemerintah mengambil sikap untuk mendukung kebijakan tersebut, berbeda dengan PAN yang memilih ber- 
sikap kritis. Bagi PKS, menaikkan harga BBM adalah wujud kepedulian pemerintah terhadap rakyatnya, yakni mengurangi subsidi yang selama ini dinikmati golongan menengah ke atas. Sementara itu bagi PAN, kenaikan harga BBM adalah kebijakan yang tidak memihak kepentingan rakyat karena akan berdampak pada kenaikan harga-harga kebutuhan lain.

Quasi logis ketidaksesuaian merupakan pernyataan yang berisi dua pilihan yang bertentangan dan terjadi pada waktu bersamaan (bandingkan dengan silogisme disjungtif). Jadi, pada waktu bersamaan seseorang melakukan dua hal yang bertentangan seperti orang yang menganjurkan berolahraga, tapi dia juga berjualan rokok. Dalam debat politik, ketidaksesuaian dapat ditelaah melalui data berikut.

\section{[2] Hanura:}

Partai Hanura tidak mengajarkan klaim. Dengan mengatakan bahwa seseorang itu bersih, peduli, profesional, ia mengklaim dirinya seperti itu. Saatnya hati nurani bicara. (2.1.1.A2.01)

Hanura mengatakan tidak mengajarkan klaim, tapi di saat yang sama ia melakukan klaim, yaitu saatnya hati nurani bicara. Ada ketidaksesuaian antara apa yang dikatakan di awal dan yang dikatakan di akhir. Di awal dia mengatakan, "Partai Hanura tidak mengajarkan klaim". Namun di akhir dia mengatakan, "Saatnya hati nurani bicara". Dengan mengatakan "Saatnya hati nurani bicara" berarti Hanura juga dengan sadar atau tidak telah membuat klaim bahwa dirinya berbicara dengan hati nurani (bukan karena motivasi politik atau lainnya).

Dalam quasi logis pertukaran, ada hubungan hipotetis antara dua kondisi dan mengimplikasikan adanya ketergantungan antarkondisi itu (bandingkan dengan silogisme kondisional). Dalam sebuah tindakan, reaksi yang diterima merupakan konsekuensi dari aksi yang dilakukan sebelumnya. Data berikut patut diperhatikan.

[3] Golkar:

Bukan basa-basi. Tapi kita melihat sekarang kepentingannya setelah bagaimana kondisi harapan hubungan dengan-....dengan....mesra dengan Demokrat ternyata seperti semu gitu. Yang semu itu kita jawab dengan tegas bahwa semua DPD meminta kepada pak JK. Ini yang saya katakan tadi. (2.1.1.A3.01)

Pada data di atas, ada dua proposisi tunggal yang saling berkaitan, yakni (1) Demokrat tidak serius menjaga duet SBY-JK, dan (2) Golkar memutuskan untuk mencalonkan JK sebagai Capres. Penalaran Quasi logis timbal balik di atas dapat di rekonstruksi sebagai berikut: Karena Demokrat tidak serius merawat dwitunggal SBY-JK, maka Golkar akan mengajukan JK sebagai Capres.

Penalaran quasi logis dalam debat politik di TV mirip dengan silogisme, yakni terdiri dari premis mayor, premis minor, dan simpulan. Quasi logis transitivitas dalam debat politik di TV memenuhi empat kriteria, yakni (1) terdiri atas tiga terma, (2) premisnya benar, (3) ketiga termanya dapat direkonstruksi kembali untuk menyatakan klasifikasi sederhana, dan (4) terma tengah terdapat dalam dua premis. Quasi logis ketidaksesuaian yang ditemukan sama dengan pertentangan dan silogisme disjungtif, yakni ada dua pilihan dalam waktu bersamaan yang harus dipilih salah satunya. Sementara itu quasi logis pertukaran atau timbal balik yang ditemukan menyerupai silogisme kondisional, yakni adanya hubungan timbal balik antara dua kondisi yang saling bergantungan. Misalnya, pernyataan Golkar "Jika teman-teman di Demokrat tidak sungguh-sungguh menjaga dwi-tunggal (SBY-JK), maka Golkar akan berpikir untuk maju sendiri (dalam pilpres 2009)". 
Penalaran analogi dilakukan dengan cara menyifati objek yang belum diketahui dengan sifat objek yang telah diketahui. Analogi dapat juga dinyatakan sebagai penarikan simpulan berdasarkan kesamaan sifat yang dimiliki oleh objek yang berbeda. Atau, analogi merupakan penalaran yang berpedoman pada kondisi yang terjadi di masa lalu juga akan terjadi di masa yang akan datang. Penalaran analogi dalam debat politik dibedakan menjadi analogi literal dan analogi figuratif.

Dalam analogi literal, dua objek dari kelas yang sama dibandingkan kesamaannya. Kemudian disimpulkan bahwa karakteristik yang dimiliki oleh objek yang sudah diketahui itu juga dimiliki oleh objek yang belum diketahui.

\section{[4] PKS:}

Tahun 2004 setelah Golkar masuk koalisi, pemerintahan menjadi kacau. PKS tidak ingin itu terjadi pada 2009. (2.1.1.B1.01)

Proposisi di atas mengandung analogi, yakni penalaran yang berpedoman pada kondisi yang terjadi di masa lalu juga akan terjadi di masa yang akan datang. Pada pemilu 2004, Golkar berada di luar koalisi, namun kemudian masuk koalisi di tengah jalan ketika JK yang saat itu terpilih menjadi wapres kemudian dipilih juga menjadi ketua umum Golkar. Masuknya Golkar dalam koalisi membuat pemerintahan menjadi kacau, misalnya, muncul tuntutan reshuffle kabinet. PKS ingin Golkar memiliki sikap yang jelas di pemilu 2009 agar tidak mengganggu koalisi lagi seperti Golkar di tahun 2004. Penalaran ini dilakukan PKS untuk menanggapi keengganan Golkar mengumumkan calon pasangan Capres-Cawapres 2009.

Dalam analogi figuratif, dua objek yang beda kelasnya dibandingkan kemiripannya. Kemiripan dalam hal ini adalah kemiripan metaforis dan ilustratif agar sebuah objek lebih mudah dipahami.
[5] PKS:

Peduli bukan dalam model baku. Apa ibu yang peduli berarti yang nilai anaknya bagus? Tercukupi gizinya? Banyak ibu-ibu miskin yang peduli, tapi karena keterbatasan kemampuan, mereka tidak mampu memenuhi. Jadi, peduli itu sesuatu yang abstrak, tapi dapat dinikmati. (2.1.1.B2.01)

Pada data di atas, PKS melakukan penalaran analogi figuratif, yakni menyamakan kepedulian pemerintah terhadap rakyatnya dengan kepedulian seorang ibu terhadap anaknya. Keterbatasan kemampuan pemerintah untuk mensejahterakan rakyatnya disamakan dengan ketidakmampuan seorang ibu untuk membahagiakan anaknya, meskipun ia sangat menginginkannya.

Analogi yang ditemukan dalam debat politik di TV lebih banyak analogi figuratif dibanding analogi literal. Artinya, analogi figuratif lebih sering digunakan oleh peserta debat politik di TV, misalnya analogi pemerintah dengan orang tua, kambing yang punya susu dan pengusaha punya namanya. Dalam analogi ini, peserta debat politik menyerupakan dua objek berdasarkan sifat-sifat yang dimilikinya. Pemerintah disamakan dengan orang tua dalam tanggung jawabnya melindungi, mencukupi, dan membahagiakan anak. Kambing punya susu, pengusaha punya namanya disamakan dengan partai yang mengangap keberhasilan pemerintah sebagai keberhasilan partainya.

Generalisasi merupakan bentuk penalaran yang mendasarkan pada prinsip bahwa kebenaran yang terdapat pada sebagian anggota kelas merupakan kebenaran juga pada anggota lainnya atau keseluruhan anggota pada kelas itu. Berikut ini adalah contoh penalaran generalisasi dalam debat politik di TV.

[6] PAN:

Tadi Bang Napitupulu, Saya pake jangan nama Bang, Bung lah, biasa make 
nama dulu, Golkar masih seperti yang dulu, katanya. (2.1.1.C.01)

Data di atas menunjukkan bahwa PAN melakukan generalisasi dengan mengatakan Golkar masih seperti yang dulu. PAN melihat beberapa kader Golkar masih bersikap seperti dulu ketika Golkar menjadi mayoritas tunggal. Oleh karena itu PAN melakukan generalisasi bahwa Golkar masih seperti yang dulu. Padahal mungkin saja banyak kader Golkar yang sudah menjadi reformis sehingga Golkar sekarang tidak lagi seperti Golkar yang dulu.

Generalisasi yang diakukan peserta debat politik di TV didasarkan prinsip bahwa apa yang terjadi pada sebagian juga terjadi pada keseluruhan. Genaralisasi ini berangkat dari beberapa kasus menuju keseluruhan. Misalnya, PAN membuat generalisasi bahwa kader Golkar yang maju dalam pileg dan pilpres adalah $4 \mathrm{~L}$ (lu lagi lu lagi), kader yang sudah tua-tua. Ini didasarkan pada kenyataan bahwa beberapa kader Golkar yang maju dalam pileg dan pilpres adalah orang-orang tua yang sudah berkali-kali menjabat.

Penalaran kausalitas terdiri dari sebab dan akibat. Karena itu, penalaran kausalitas bersifat rangkaian, yakni satu peristiwa terjadi karena disebabkan oleh peristiwa yang mendahuluinya. Premis-premis dalam penalaran kausalitas memiliki hubungan sebab-akibat, yakni suatu peristiwa menyebabkan peristiwa lain terjadi. Peristiwa yang mendahului (sebab) menyebabkan peristiwa setelahnya (akibat). Berikut ini merupakan contoh penalaran kausalitas dalam debat politik.

[7] PKS:

Katakanlah Pak JK tidak dipecat, tapi kemudian Pak JK berhadapan dengan Golkar, dia ikut Pak SBY menghadapi apa yang didukung oleh Golkar yaitu Ibu Megawati dan Pak Hasyim Muzadi. Tiba-tiba kemudian yang menang ternyata Pak JK, lalu kemudian Golkar kembali mendukung Pak JK jadi ketua umum. Masuknya Golkar di dalam koalisinya SBY-JK inilah yang membuat kekacauan. (2.1.1.D.01)

Apa yang ingin dikatakan oleh PKS adalah bahwa sebelum Golkar masuk koalisi, pemerintah berjalan normal-normal saja. Kemudian, Golkar masuk dalam koalisi. Setelah itu, pemerintah melakukan reshuffle kabinet dua kali. Jadi, masuknya Golkar dalam koalisi menyebabkan reshuffle kabinet dua kali. Hal tersebut menurut PKS menyebabkan kekacauan. Ini terjadi, menurut PKS, karena suara partai wapres lebih besar dibanding suara partai presiden (perolehan suara dalam pemilu legislatif suara Golkar lebih tinggi dari Demokrat, partainya Presiden).

Dalam debat politik juga terdapat kausalitas yang lebih kompleks, yakni satu sebab mengakibatkan akibat yang menjadi sebab bagi akibat berikutnya. Data berikut patut diperhatikan.

[8] Prabowo:

Saya berpendapat bahwa konflikkonflik itu terjadi, karena sistim kita tidak bisa memberi penghidupan yang baik. Kalau menurut saya kembali tadi juga di singgung Pak WIRANTO, kebutuhan dasar manusia. Jadi, ediologi apapun, falsafah apapun, ujungnya adalah apakah warga Negara tersebut merasa dia sudah dapat terpenuhi kebutuhankebutuhan dasar dia, apa dia sudah merasa aman, apa dia sudah mendapat sekolah yang baik untuk anaknya, apa dia cukup makan untuk dirinya dan keluarganya. Manakala dia merasa tidak terpenuhi kebutuhan dasar, (maka) timbullah frustasi, timbullah ekstrenisme, timbullah radikalisme, dan mudah sekali dipicu konflikkonflik tersebut. (2.1.1.D.02)

Menurut Prabowo, konflik-konflik itu terjadi sebagai akibat dari sistem yang tidak bisa memberi penghidupan 
yang baik. Jadi yang menjadi sebab adalah "Sistem yang tidak bisa memberi penghidupan yang baik" dan akibatnya adalah "Terjadi konflik-konflik".

Penalaran kausalitas yang dilakukan peserta debat politik begerak dari sebab menuju akibat atau akibat menuju sebab. Ketika ada sebuah akibat, maka peserta debat politik mencoba memahami penyebabnya. Dalam menilai kausalitas, ada tiga hal yang perlu diperhatikan, yakni kualitas, kuantitas, dan oposisi. Dari sisi kualitas, sebab harus benar-benar menjadi penyebab akibat. Secara kuantitas, sebab-sebab yang ada memang cukup untuk menimbulkan akibat. Sedangkan oposisi yang dimaksud adalah tidak ada sebab-sebab lain yang menimbulkan akibat tersebut. Namun, dalam debat politik sering terjadi kesulitan untuk menentukan penyebabnya karena banyak akibat yang ditimbulkan oleh berbagai sebab. Dengan kata lain, dalam politik banyak sekali satu akibat yang tidak disebabkan oleh sebab tunggal.

Penalaran koeksistensial memiliki kesamaan dengan penalaran kausalitas, yakni adanya dua premis yang berkaitan. Namun, penalaran koeksistensial mensyaratkan tanda dan kondisi hadir bersamaan. Penalaran ini memiliki dua jenis, yakni koeksistensial tindakan/orang dan koeksistensial kewenangan.

\section{Koeksistensial tindakan}

Dalam koeksistensial tindakan, karakter seseorang atau sesuatu disimpulkan berdasarkan tindakannya. Perhatikan data berikut ini.

[9] Golkar:

Di masa lalu, Golkar dipercaya untuk memimpin negeri ini. Sekarang, kader Golkar ikut menjadi bagian dari pemerintahan. Saya yakin, pada pemilu 2009 ini Golkar masih mendapatkan kepercayaan itu. (2.1.1.E1.01)
Golkar menyatakan bahwa di masa lalu, Golkar dipercaya untuk memimpin negeri ini. Sekarang, kader Golkar ikut menjadi bagian dari pemerintahan. Sehingga dapat disimpulkan bahwa pada pemilu 2009 ini, Golkar akan menjadi bagian pemerintahan lagi. Dengan pengalaman masa lalu dan masa kini, Golkar yakin bahwa di pemilu 2009 yang sebentar lagi dilaksanakan Golkar mendapat kepercayaan rakyat untuk menjadi bagian dari pemerintahan.

Koeksistensial tindakan juga dilakukan oleh PKS terhadap perilaku Golkar di pilpres 2004.

\section{[10] PKS:}

Yang artinya begini, kan kami juga belajar, ternyata Golkar di 2004 walaupun suaranya jauh lebih besar ternyata bersedia menjadi cawapres dari capres yang partainya suaranya lebih kecil (Demokrat, pen). Nah, barangkali 2009 mau jadi cawapres kami (PKS, pen). (2.1.1.E1.02)

Pada data di atas, PKS melakukan penalaran koeksistensial tindakan. PKS melihat bahwa Golkar di pilpres 2004 bersedia menjadi wapres dari Demokrat yang suaranya lebih kecil. Oleh karena itu, PKS menyimpulkan bahwa Golkar juga mungkin bersedia menjadi cawapres PKS di pilpres 2009. Memang pada pilpres 2004 Golkar tidak mencalonkan JK sebagai cawapres SBY, namun setelah pasangan SBY-JK ternyata menang atas pasangan Mega-Hasyim, Golkar mendukung JK menjadi ketua umum Golkar dan sekaligus Golkar masuk menjadi bagian koalisi pemerintah.

Koeksistensial kewenangan merupakan penalaran yang didasarkan pada keyakinan bahwa seseorang atau sesuatu memiliki pengetahuan lebih tentang suatu masalah. Berikut ini contoh penalaran koeksistensial kewenangan dalam debat politik di TV. 
[11] PKS:

Prof. Syafi'i Ma'arif mengatakan bahwa Pak JK the real president. Banyak orang marah-marah karena menganggap seolah-olah itu tidak santun gitu, padahal mungkin kenyataannya Pak JK lebih bekerja dari pada SBY. (2.1.1.E1.03)

Pada data di atas, PKS melakukan penalaran koeksistensial kewenangan. Prof. Syafi'i Ma'arif dianggap memiliki otoritas untuk menilai apakah benar bahwa wapres JK lebih berperan dalam pemerintahan dibanding presiden SBY. Bagi PKS, Buya Syafi'i Ma'arif dianggap memiliki kewenangan karena ia disamping seorang intelektual muslim, tokoh Muhammadiyah, juga pengamat politik. Dengan melakukan itu, PKS merasa aman karena lawan debat dihadapkan langsung dengan Prof. Syafi'i Ma'arif. Bahkan pada kesempatan lain PKS juga menggunakan kewenangan media massa untuk memojokkan Golkar.

Pada data berikut ini Prabowo sengaja menyebut nama Wiranto dalam mengemukakan pendapat tentang relasi agama dan negara. Tujuannya adalah agar jika lawan debat (Budiono) menyerang Prabowo, Wiranto ikut betanggung jawab mempertahankan pernyataan tersebut karena sebenarnya Wiranto yang lebih dahulu berpendapat demikian. Berikut ini pernyataan Prabowo:

[12] Prabowo:

Saya melihat sama dengan pak Wiranto dalam perjalanan bangsa kita akan terjadi integrasi nasional, kawin antarsuku. Saya kok lebih optimis masalah itu. Saya tidak terlalu kawatir yang penting kembali lagi kita bisa memenuhi kebutuhankebutuhan dasar rakyat kita. Kalau kita tidak bisa memenuhi apapun, saya kira rakyat itu akan mengatur dirinya sendiri. Dia tidak mau diatur oleh suatu pemerintah yang tidak bisa memberi kebutuhan dasar dia. Banyak orang didaerah-daerah mengatakan kalau Jakarta tidak bisa mengurus kita, marilah kita urus kita sendiri. (2.1.1.E2.03)

Data di atas dinyatakan oleh Prabowo dalam debat cawapres bertajuk "Pembangunan jati diri bangsa", khususnya pada masalah hubungan antara agama dan negara. Prabowo merasa optimis bahwa bangsa Indonesia akan tetap bersatu dalam wadah NKRI selama Negara mampu memberikan kebutuhan dasar rakyatnya. Jika Negara tidak mampu memenuhi kebutuhan dasar rakyat, maka rakyat akan mengatur dirinya sendiri (terjadi disintegrasi).

Koeksistensial yang ditemukan terdiri dari koeksistensial tindakan dan kewenangan. Dalam penalaran ini antara tanda dan kondisi hadir secara bersama. Koeksistensial tindakan dalam debat politik sering berkaitan dengan karakter partai politik. Sedangkan koeksistensial kewenangan lebih banyak berkaitan dengan kepakaran seseorang atau lembaga survey. Artinya, peserta debat politik di TV sering mengutip pendapat pakar atau hasil survey suatu lembaga. Jika orang yang dianggap memiliki kewenangan ternyata tidak ahli di bidang yang dibahas, maka penalaran tersebut termasuk dalam kesesatan argumentum ad verecundiam.

\section{Penalaran Disosiatif}

Penalaran disosiatif merupakan tindakan berpikir untuk membedakan satu gagasan dari gagasan yang lainnya dan berusaha menilai kedua gagasan tersebut. Dalam penalaran ini, penutur memiliki hirarkhi nilai yang diyakini, yakni gagasan yang satu lebih baik dari yang lainnya. Disosiasi meliputi ideologi, nilai, moral, dan kebijakan.

Disosiasi ideologi merupakan hirarkhi ideologi yang dimiliki oleh penutur. Penutur meyakini bahwa satu ideologi lebih tinggi nilainya dibanding ideologi 
lain. Dalam debat politik di TV, penutur menganggap bahwa ideologi yang diyakini lebih baik dari ideologi yang diyakini lawan debatnya. Data berikut patut diperhatikan.

[13] Prabowo:

Di bidang pendidikan kita akan memperjuangkan 12 tahun wajib belajar dengan seluruh biaya ditanggung oleh pemerintah. Kemudian kita menolak undang-undang BHP. Undangundang BHP adalah tidak sesuai dengan undang-undang dasar 1945. Komersialisasi pendidikan tinggi bukan merupakan sistem pancasila. (Ia) berada diluar sistem kekeluargaan yang dianut oleh pendiri-pendiri bangsa kita. (Ia) tidak sesuai dengan demokrasi. (Ia) tidak memungkinkan orang miskin bisa sekolah tinggi. (seharusnya) Anaknya orang miskin bisa sekolah tinggi. (2.1.2.02)

Data di atas menunjukkan bahwa Prabowo memiliki hirarkhi ideologi yang diyakini, yakni ideologi Pancasila lebih baik dari ideologi Kapitalisme (komersialisasi pendidikan Tinggi). Prabowo menolak UUBHP (Badan Hukum Perguruan Tinggi) karena bertentangan dengan UUD 45 dan Pancasila. Jika UUBHP dilaksanakan, maka rakyat miskin tidak mungkin bisa kuliah. Ini tidak sesuai dengan demokrasi dalam pendidikan, yakni setiap warga negara berhak mendapatkan pendidikan.

Selain disosiasi ideologi, dalam debat politik di TV juga ditemukan disosiasi kebijakan. Perhatikan data berikut.

[14] Prabowo:

Ibu Megawati dan saya bertekat untuk mengembalikan jati diri bangsa melalui program ekonomi kerakyatan.... Tidak mungkin kita bicara pembangunan jati diri bangsa tanpa kita menyelesaikan masalah yang paling kunci yaitu menyelamatkan sumber daya ekonomi, menyelamatkan kekayaan nasional, tidak terus-menerus bocor keluar negeri. Kita tidak ingin jati diri bangsa kita adalah bangsa penyuplai tenaga kerja murah, bangsa pasar bagi barang-barang orang lain, kemudian sumber bahan baku bagi bangsa-bangsa lain, dan rakyat kita terus dalam keadaan miskin. Kami mengusung perubahan. Rakyat yang akan diberi kesempatan tanggal 8 juli yang akan datang, apakah akan memilih perubahan, memilih kembali ke jati diri bangsa sesuai cita-cita pendiri bangsa kita, cita-cita bung KARNO dan bung HATTA dan sekian ribu pejuang-pejuang yang mati untuk republik ini, atau kita melanjutkan sistem ekonomi yang sudah terbukti tidak berhasil membawa manfaat kepada rakyat banyak. Terima kasih. (2.1.2.01)

Ada hirarkhi nilai kebijakan yang diyakini oleh penutur, yakni sistem ekonomi kerakyatan yang diusungnya dengan sistem ekonomi yang sedang dijalankan oleh pemerintah sekarang (ekonomi yang berkiblat ke Barat; kapitalis). Sistem ekonomi kerakyatan akan membawa rakyat kepada kehidupan yang makmur dalam keadilan dan adil dalam kemakmuran. Sementara sistem ekonomi kapitalis membawa rakyat ke dalam kemiskinan. Dengan sistem ekonomi kapitalis, bangsa terbukti hanya menjadi bangsa penyuplai tenaga kerja murah, bangsa pasar bagi barang-barang orang lain, dan sumber bahan baku bagi bangsa-bangsa lain. Karena itu, bangsa Indonesia terus dalam keadaan miskin.

Hirarkhi nilai juga disampaikan Prabowo ketika menyampaikan visi dan misi di bidang pendidikan. Berikut pernyataan Prabowo:

[15]Di bidang pendidikan kita akan memperjuangkan 12 tahun wajib belajar dengan seluruh biaya ditang- 
gung oleh pemerintah. Kemudian kita menolak undang-undang BHP, undang-undang BHP adalah tidak sesuai dengan undang-undang dasar 1945. Komersialisasi pendidikan tinggi bukan merupakan sistem pancasila berada diluar sistem kekeluargaan yang dianut oleh pendiri-pendiri bangsa kita, tidak sesuai dengan demokrasi, tidak memungkinkan orang miskin bisa sekolah tinggi, anaknya orang miskin bisa sekolah tinggi. (2.1.2.02)

Pada data di atas, Prabowo ingin memperjuangkan wajib belajar 12 tahun dengan seluruh biaya gratis. Berbeda dengan pemerintahan sekarang yang mengiklankan pendidikan gratis, namun kenyataannya justru biaya pendidikan semakin mahal. Prabowo mangatakan,

“....walaupun ada iklan-iklan yang mengatakan pendidikan gratis, kenyataannya yang saya ketemukan di kabupaten-kabupaten dari Sabang sampai Merauke kalau itu tidak benar. Rakyat kita tidak merasa pendidikan itu gratis...." (DCWP2).

Prabowo juga menolak UU BHP Perguruan Tinggi karena itu merupakan komersialisasi pendidikan yang tidak sejalan dengan UUD 45, Pancasila, dan asas kekeluargaan. Jika BHP disahkan dan dilaksanakan, maka anak-anak dari kalangan rakyat miskin tidak bisa kuliah karena tidak mampu membayar uang kuliah yang mahal.

Penalaran disosiatif yang ditemukan dalam debat politik di TV adalah ideologi dan kebijakan. Dalam debat politik di TV penalaran disosiatif didasarkan atas perbedaan nilai yang diyakini oleh peserta debat. Dalam disosiasi ideologi, ada dua ideologi yang dianggap berbeda dan salah satunya lebih baik dari yang lain menurut pembicara. Misalnya, ideologi Pancasila dianggap lebih baik dibanding ideologi Kapitalis. Dalam disosiasi kebijakan, ada kebijakan pemerintah yang dinilai tidak benar menurut kebijakan yang dimilikinya. Misalnya, Prabowo menganggap kebijakan membuat perguruan tinggi menjadi Badan Hukum Negara (BHN) sebagai kebijakan yang berorientasi pada ekonomi liberal dan bertentangan dengan sistem pendidikan yang berdasarkan Pancasila.

\section{SIMPULAN}

Dalam debat politik di TV, ditemukan penalaran asosiatif dan disosiatif dengan seluruh ragam dan subragamnya. Penalaran asosiatif yang ditemukan dalam debat politik di TV adalah (1) quasi logis, (2) analogi, (3) generalisasi, (4) kausalitas, dan (5) koeksistensial. Quasi logis yang ditemukan dibedakan ke dalam transitivitas, ketidaksesuaian, dan pertukaran. Analogi yang ditemukan terdiri dari analogi literal dan figuratif. Generalisasi dan kausalitas tidak memiliki ragam. Koeksistensial yang ditemukan terdiri dari koeksistensial tindakan dan kewenangan. Sementara itu, penalaran disosiatif yang ditemukan terdiri atas ideologi dan kebijakan.

Berdasarkan temuan tersebut dapat disimpulkan bahwa pendirian dalam debat politik lahir dari sudut pandang yang beragam sesuai logika dan kepentingan politik masing-masing peserta debat. Perbedaan sudut pandang yang digunakan menyebabkan perbedaan penilaian terhadap suatu masalah politik yang diperdebatkan. Perbedaan tersebut semakin besar jika dipengaruhi oleh kepentingan politik yang diperjuangkan oleh peserta debat. Penalaran dalam debat politik lebih dipengaruhi oleh motivasi politik, bukan kebenaran logis. Karena motivasi tertentu, yakni demi kalkulasi dan kepentingan politiknya peserta debat politik sering melakukan kesalahan penalaran. Kesalahan penalaran sering terjadi karena peserta debat memanfaatkannya sebagai strategi berdebat. Hal ini menunjukkan bahwa penalaran dalam debat politik tidak sekedar 
pertarungan logika melainkan juga pertarungan kepentingan. Temuan penelitian ini menguatkan anggapan bahwa bahasa memiliki relasi dengan pikiran (Chomsky, 1972) dan kekuasaan (Bourdeiu, 1991; Fairclough, 2001; dan Chomsky, 2004).

\section{UCAPAN TERIMA KASIH}

Artikel ini diangkat dari penelitian mandiri swadana yang dilaksanakan pada tahun 2009-2011. Ucapan terima kasih disampaikan kepada para mahasiswa yang membantu mentranskripsikan sumber data, debat partai dan debat capres. Ucapan terima kasih juga disampaikan kepada teman sejawat yang menjadi mitra diskusi sejak penngumpulan data, analisis data, sampai verifikasi dan trianggulasi data dan hasil penelitian.

\section{DAFTAR RUJUKAN}

Bourdeiu, Pierre. 1991. Language and Symbolik Power. Cambridge, Massachusetts: Harvard University Press.

Chomsky, Noam. 1972. Language and Mind. New York: Hardcourt Brace Jovanovich, Inc.

Chomsky, Noam. 2004. Language and Politics. UK: AK Press.

Copi, Irving M. 1982. Introduction to Logic. New York: Macmillan Publishing Co., Inc.

Dawud. 1998. Penalaran dalam Tuturan BI Siswa SD. Disertasi tidak diterbitkan. Malang. PPS UM Malang.

Fairclough, Norman. 2001. Language and Power. England: Pearson Education Limited.

Hess-Luttich, Ernest. W.B. 2007. (Pseudo)Argumentation in TV Debate. Journal of Pragmatics 39 (2007). hal. 1360-1370. available online at www.scinecedirect. com. Diakses 25 Oktober 2009.
Laurbach, Gerda. 2007. Argumentation in Political Talk-Shows Interviews. Journal of Pragmatics 39 (2007) 1371-1387. available online at www.sciencedirect. com. Diakses 25 Oktober 2009.

Luginbuhl, Martin. 2007. Conversational Violance in Political TV Debat: Forms and Functions. Journal of Pragmatics 39 (2007) 1371-1387. available online at www.sciencedirect.com. Diakses 25 Oktober 2009.

Miles, Mattew B. dan Huberman, A. Michael. 1992. Analisis Data Kualitatif. (terj. Tjejep Rohendi Rohidi). Jakarta: Penerbit Universitas Indonesia.

Rahardjo, Mudjia. 2007. Hermeneutika Gadamerian: Kuasa Bahasa dalam Wacana Politik Gus Dur. Malang: UIN Malang Press.

Santoso, Anang. 2003. Penggunaan Bahasa Indonesia dalam Wacana Politik Pasca Era Orde Baru. Disertasi tidak diterbitkan. Malang: PPS UM Malang.

Sullivan, Daniel, J. 1963. Fundamentals of Logic. New York: McGrow-Hill, Inc.

Toulmin, Stehen, E., Rieke, R., dan Janik, A. 1979. An Introduction to Reasoning. New York: Macmillan Publishing. Co. Inc.

Toulmin, Stephen, E. 1990. The Use of Argument. Cambridge: University Press.

Vedung, Evert. 1982. Political Reasoning. London: Sage Publication.

Warnick, Barbara dan Inch, Edward S. 1994. Critical Thinking and Communication: The Use of Reason in Argument. New York: Macmillan Publishing Company.

Wiyanto, Asul. Tt. Debat sebagai Retorika. Semarang: CV Aneka Ilmu. 